\title{
Management of Extra-Hepatopulmonary Hydatid Cysts (157 cases)
}

\section{Ekstra Hepato-Pulmoner Hidatik Kist Deneyimlerimiz (157 olgu)}

\author{
Murat Çakır ${ }^{1}$, Mehmet Balasar², Tevfik Küçükkartallar ${ }^{1}$, Ahmet Tekin ${ }^{1}$, Adil Kartal ${ }^{1}$, Ömer Karahan³, \\ Süleyman Kargın
}

1Department of General Surgery, Necmettin Erbakan University Meram School of Medicine, Konya, Turkey

2Department of Urology, Necmettin Erbakan University Meram School of Medicine, Konya, Turkey

${ }^{3}$ Clinic of General Surgery, Konya Training and Research Hospital, Konya, Turkey

\section{ABSTRACT}

Objective: Hydatid cyst disease (HCD) is a zoonotic infestation of Echinococcus granulosus, which is frequently seen in some regions of the world. Unusual localization of Echinococcus granulosus is very rare. Hence, we would like to present our experience of identifying an extra-hepatopulmonary location of hydatid cysts.

Methods: A total of 157 patients with an unusual location of hydatid cysts treated between 2000 and 2012 were retrospectively evaluated according to their age, sex, symptoms, diagnosis, stage, location of the cyst, and treatment modality.

Results: Out of 157 patients, 68 were male and 89 were female. The mean age was 43.65 (4-85) years. The most involved organ was the spleen. The cysts were classified in 96, 57, and 4 patients as type I-II, III, and IV-V, respectively.

Conclusion: The Puncture, Aspiration, Injection, and Reaspiration regimen should be the primary treatment option for hydatid cysts with unusual locations. As much as possible, organ-preserving surgery should be a treatment of choice in extra-hepatopulmonary hydatid cysts. Keywords: Hydatid cyst, extra-hepatopulmonary, location, surgery

Geliş Tarihi: 01.10.2015 Kabul Tarihi: 23.05.2016

\section{Öz}

Amaç: Hidatik kist hastalığı (HKH), dünyanın belirli bölgelerinde sık görülen Echinococcus granulosus'un neden olduğu zoonotik bir enfestasyondur. Echinococcus granulosus'un olağan dışı yerleşimi çok nadirdir. Bu nedenle biz ekstrahepato-pulmoner yerleşimli hidatik kist deneyimlerimizi sunuyoruz.

Yöntemler: 2000-2012 Yılları arasında tedavi edilen ve nadir yerleşim gösteren toplam 157 hidatik kist hastası yaş, cinsiyet, semptom, tanı, evre, yerleşim yeri ve tedavi yöntemine göre retrospektif olarak değerlendirildi.

Bulgular: 157 hastanın 68'i erkek ve 89'u kadındı. Yaş ortalaması 43,65 (4-85) idi. En çok tutulan organ dalaktı. Kistler sırasıyla 96,57 ve 4 hastada Tip I-II, III ve IV-V olarak sınıflandırıldı.

Sonuç: Olağan dışı yerleşimli hidatik kistlerde PAiR öncelikli tedavi yöntemi olmalı. Ekstrahepato-pulmoner yerleşimli hidatik kist hastalarında mümkün olduğunca organ koruyucu cerrahi tedavi tercih edilmelidir.

Anahtar Kelimeler: Hidatik kist, ekstrahepato-pulmoner, yerleşim, cerrahi

Received: 01.10 .2015

Accepted: 23.05.2016

\section{INTRODUCTION}

Hydatid cyst is a zoonotic infestation caused by Echinococcus granulosus. It is frequently seen in Mediterranean countries, the Middle East, South America, New Zealand, Australia, and South-East Asia (1, 2).

Hydatid cysts most commonly invade the liver (60\%-70\%) and the lungs (20\%-25\%), but they can be located in the all parts of the body (3). In the literature, majority of extra-hepatopulmonary hydatid cysts studies depends on case presentations and small series. Because the prevalence of extrahepatopulmonary hydatid cysts is low, there are no clear staging and therapeutic modalities as seen in the liver and lung hydatid cysts. We believe that further studies should be conducted on this subject. The disease presents clinical symptoms according to the involved organ. While the small

Address for Correspondence / Yazışma Adresi: Murat Çakır E.mail: drmuratcakir@hotmail.com DOI: 10.5152/tpd.2016.4529

(C) Copyright 2016 Turkish Society for Parasitology - Available online at www.tparazitolderg.org

CTelif hakkı 2016 Türkiye Parazitoloji Derneği - Makale metnine www.tparazitolderg.org web sayfasından ulaşılabilir. 
cysts are asymptomatic, the larger ones generally are symptomatic.

The aim of this study was to present the diagnosis, classification, and particularly, management of these large series of unusual locations of hydatid cysts.

\section{METHODS}

A total of 157 hydatid cyst patients with an extra-hepatopulmonary location who were treated between 2000 and 2012 at Necmettin Erbakan University Meram School of Medicine and at Konya Training and Research Hospital, Turkey were retrospectively evaluated. The cases in the series were evaluated according to age, sex, location, presenting symptoms, diagnosis, stage, and diagnostic and treatment methods. Ethics committee approval was received for this study from the ethics committee of Necmettin Erbakan University Meram School of Medicine, Non-Invasive Clinical Research Ethics Committee. All patients were included in the consent document.

The hepatic and pulmonary involvement of the hydatid cyst is the ordinary location. Other locations are accepted as unusual. In case of unusual locations with hepatic or pulmonary hydatid involvement, these cases were accepted as secondary hydatid cysts. Patients with a previous history of hepatic and/or pulmonary hydatid cyst treatment were also regarded to have secondary cysts. The cases, however, with no hepatic and pulmonary cysts or no history of hydatid cyst treatment were accepted as a primary case. The cases with hepatic and/or pulmonary cysts with another organ involvement were not included in the study. The cases with a previous surgery of hepatic and pulmonary cysts and Puncture, Aspiration, Injection, and Reaspiration (PAIR) treatment were excluded from the study.

Imaging methods such as ultrasonography (US) and computed tomography (CT) were routinely used for diagnosis and staging according to the Gharbi classification. Magnetic resonance imaging (MRI) was performed when necessary. To rule out the remaining cavity of the treated cyst from the recurrent new cyst, CT was performed 1 month post-operatively. Serological tests were not a routine procedure. The tests were utilized in cases where imaging methods proved to be insufficient in differential diagnosis.
PAIR was the treatment of choice for early-stage hydatid cysts. A minimally invasive procedure of classical surgery (laparoscopic surgery) was the other treatment modality

\section{RESULTS}

Out of 157 patients, 68 were male and 89 were female. The mean age was 43.65 (4-85) years. Although 128 out of 157 patients had single organ involvement, 29 patients had multiple organ involvement. The most involved organ was the spleen, with a $21.7 \%$ ratio of occurrence. The other involved organs are listed in Table 1.

The most common symptom was abdominal pain, with a $49.7 \%$ ratio. It was followed by low back pain with a $16.6 \%$ ratio, back pain with $12.7 \%$, extremity pain and swelling with $7.6 \%$, chest pain with $3.8 \%$, dyspnea with $3.8 \%$, menstrual irregularity with $3.2 \%$, mass in the breast with $1.9 \%$, and headache with $0.6 \%$ (Table 2).

Indirect hemagglutination (IHA) values were preoperatively analyzed in 61 patients, of whom 43 showed a positive result. Hydatid cysts were staged in 96, 57, and 4 patients as Type I-II, Type III, and Type IV-V, respectively.

The most frequently used treatment tool was PAIR (26.8\%), which was the treatment of choice for Type I-II cysts. Total cystectomy (24.8\%), unroofing, and drainage to the peritoneal cavity (19.8) were performed laparoscopically or by open surgery. Splenectomy (10.2\%), oopherectomy (7.6\%), partial nephrectomy (3.2\%), nephrectomy (2.5\%), and distal pancreatectomy (1.6\%) were the other surgical modalities. One patient underwent thyroidectomy, and four underwent laminectomy (Table 3).

\section{DISCUSSION}

Echinococcus granulosus embryos, which pass through the intestinal wall, are most frequently located in the liver and lungs (3). Unusual hydatid cyst localization other than the peritoneal cavity is defined as the spread of the embryos into the systemic circulation by escaping the hepatic and pulmonary filter mechanisms. Majority of the unusual localization of cysts series are primary. It is possible that lymphatic spread in both intramuscular and subcutaneous tissue localizations besides systemic spread might

Table 1. The distribution of cysts according to involved organs

\begin{tabular}{|c|c|c|c|c|c|}
\hline Organ & The number of cases & $\%$ & Organ & The number of cases & $\%$ \\
\hline Ovary & 12 & 7.6 & Uterus & 5 & 3.2 \\
\hline Omentum & 11 & 7 & Pancreas & 4 & 2.5 \\
\hline Retroperitoneal space & 11 & 7 & Muscle Iliopsoas & 4 & 2.5 \\
\hline Kidney & 11 & 7 & Heart & 2 & 1.3 \\
\hline Pelvis & 10 & 6.4 & Brain & 1 & 0.6 \\
\hline Mesentery & 10 & 6.4 & Thyroid & 1 & 0.6 \\
\hline Neck & 5 & 3.2 & Total & 157 & 100 \\
\hline
\end{tabular}


Table 2. The distribution of symptoms of the cases

\begin{tabular}{|l|c|c|}
\hline Symptoms & The number of cases & $\%$ \\
\hline Abdominal pain & 78 & 49.7 \\
\hline Low back pain & 26 & 16.6 \\
\hline Back pain & 20 & 12.7 \\
\hline Extremity pain and swelling & 12 & 7.6 \\
\hline Chest pain & 6 & 3.8 \\
\hline Dyspnea & 6 & 3.8 \\
\hline Menstrual irregularity & 5 & 3.2 \\
\hline Mass in the breast & 3 & 1.9 \\
\hline Headache & 1 & 0.6 \\
\hline Total & 157 & 100 \\
\hline
\end{tabular}

Table 3. The treatment method applied to the cases

\begin{tabular}{|l|c|c|}
\hline The treatment method & The number of cases & $\%$ \\
\hline PAir & 42 & 26.8 \\
\hline Total cystectomy & 39 & 24.8 \\
\hline Unroofing & 31 & 19.8 \\
\hline Splenectomy & 16 & 10.2 \\
\hline Oophorectomy & 12 & 7.6 \\
\hline Partial nephrectomy & 5 & 3.2 \\
\hline Nephrectomy & 4 & 2.5 \\
\hline Laminectomy & 4 & 2.5 \\
\hline Distal pancreatectomy & 3 & 1.9 \\
\hline Thyroidectomy & 1 & 0.6 \\
\hline Total & 157 & 100 \\
\hline
\end{tabular}

have been an effective transfer route (4). A hydatid cyst case that occurred after a bee sting also supports this idea (5). According to a study from the literature, hydatid cysts involve the liver $(60 \%-$ $70 \%$ ratio), the lungs $(20 \%-25 \%)$, serosal surfaces $(6 \%)$, kidneys $(2.9 \%)$, spleen $(0.5 \%)$, and other organs (6). The data offered by this study were not similar to our result regarding the spleen and serosal surface rates. The disease was most commonly seen in the spleen among the intraabdominal organs in our study. Hydatid cysts involve a single organ at the rate of $85 \%-90 \%$ (7). Twenty (18.5\%) of our cases showed multiple organ involvement.

Hydatid cysts do not have a specific symptom. When they reach larger sizes, they cause mass effect to the involved organ. The growth speed of the cysts varies according to the involved organ. In the past, hydatid cysts were thought to be slow-growing lesions. Many studies reported that hydatid cysts grow in human beings by approximately $1 \mathrm{~cm}$ in a year, whereas others reported that they grow by approximately $4-5 \mathrm{~cm}$ a year $(8,9)$. Therefore, It was determined that the growth rate was faster than expected (10). Cysts on serosal surfaces such as the peritoneum can reach larger sizes than those on tissues such as the bones. Therefore, hydatid cysts form pressure symptoms later on serosal surfaces. They can, however, show symptoms on the bones and intracranial fields in smaller sizes. The complicated hydatid cysts (such as rupture and infection) cause symptomology different than pressure ones. Small or calcified cysts are generally asymptomatic and maintain their status (11-13). This condition is more pronounced in hepatic hydatid cysts. The symptoms, mortality, and morbidity of hydatid cysts with unexpected involvement are different. If rupture occurs in cases with heart involvement, the disease spreads to the whole body and pericardial tamponade, which is a risky condition, might develop $(14,15)$. Surgery is necessary as soon as the patient has such a diagnosis. Heart involvement was seen in two of our cases. Their diagnosis was due to chest pain. The symptom in central nervous system involvement depends on the elevated intracranial pressure (16). Epileptic crisis and neurological deficit might develop in some cases (17). Headache due to elevated intracranial pressure was the reason of surgery in our cases. Hematuria and lumbar pain might be seen in kidney involvement (18). Bone localization can cause pathological fractures. Hydatid cysts within the parenchyma of the breast should be differentiated from the cystic disease of the breast.

Imaging techniques are significant in the diagnosis of unusual cysts. Serological tests can be utilized in the follow-up of operated cases. Kuru et al. (19) stated that the IHA test had less sensitivity in pulmonary hydatid cysts and might show false negatives in inactive or calcified cysts and therefore should be supported by another serological method. Some investigators believe that the sensitivity and specificity of the IHA test is above $90 \%(20)$. The IHA values of 61 patients in this study were detected, and the value was positive in 43 (70.3\%) cases.

Ultrasonography, CT, and MRI constitute the most frequently used imaging techniques. US is the most preferred imaging method, with a sensitivity rate of $90 \%-95 \%$. US was used in the classification of hepatic hydatid cysts $(21,22)$. CT is a more valuable imaging method than US, with a sensitivity rate of $95 \%-100 \%$. It reveals that the number, size, and anatomical localization of cysts better than USG.

Open surgery used to be considered the only treatment for hydatid cysts. Currently, laparoscopic procedures and PAIR are methods that are used alternatively to open surgery $(23,24)$. Extra-hepatopulmonary hydatid cysts are treated according to their localizations. PAIR is routinely used in Type I-II hydatid cysts with proper localization (24). PAIR is not a selective treatment for intrathoracic extra-pulmonary hydatid cysts (25). Surgical treatment is performed in cases where the cyst is infected or exists in some organs such as the brain, kidneys, and pancreas (26-27).

We prefer surgery for cysts that cannot be adequate for PAIR, for PAIR complicated cases and Type III cysts. There is no treatment for Type IV and V cysts because they are asymptomatic, as seen in our study. If there is no benefit in the protection of the organ, then these organs should be removed.

The fact that what kind of an antiparasitic treatment should be administered for extra-hepatopulmonary hydatid cysts during pre-operative and post-operative periods is still a subject of conflict (28-30). We routinely administered antiparasitic treat- 
ment for 10 days preoperatively and 3 months postoperatively by evaluating liver function.

\section{CONCLUSION}

Extra-hepatopulmonary hydatid cysts most frequently involve intraabdominal organs. The symptoms of cysts with unusual localizations are dependent on the involved organs. Hydatid cysts with unusual localizations generally fall into Type I, II, or III. The number of Type IV and V cysts is very low. Puncture, Aspiration, Injection, and Reaspiration should be the primary treatment option for hydatid cysts with unusual localizations.

Ethics Committee Approval: Ethics committee approval was received for this study from the ethics committee of Necmettin Erbakan University Meram School of Medicine, Non-Invasive Clinical Research Ethics Committee (2014/667)

Informed Consent: Written informed consent was not obtained due to the retrospective nature of the study.

Peer-review: Externally peer-reviewed.

Author Contributions: Concept - M.Ç., M.B.; Design - M.Ç., T.K.; Supervision - A.K., Ö.K.; Funding - M.Ç., S.K.; Materials - A.T.; Data Collection and/or Processing - S.K.; Analysis and/or Interpretation - M.Ç.; Literature Review - M.Ç.; Writing - M.Ç.; Critical Review - A.K.

Acknowledgement: We would like to thank Sait Bodur (MD) for contribution of statistical analysis.

Conflict of Interest: The authors declare no conflict of interest.

Financial Disclosure: The authors declared that this study has received no financial support.

Etik Komite Onayı: Bu çalışma için Necmettin Erbakan Üniversitesi Meram Tıp Fakültesi Klinik Olmayan Araştırmalar Etik Kurulu'ndan onay alınmıştır.

Hasta Onamı: Çalışmanın retrospektif tasarımından dolayı hasta onamı alınmamıştır.

Hakem Değerlendirmesi: Dış bağımsız.

Yazar Katkıları: Fikir - M.Ç., M.B.; Tasarım - M.Ç., T.K.; Denetleme - A.K., Ö.K.; Kaynaklar - M.Ç., S.K.; Malzemeler - A.T.; Veri Toplanması ve/veya İşlemesi - S.K.; Analiz ve/veya Yorum - M.Ç.; Literatür Taraması - M.Ç.; Yazıyı Yazan - M.Ç.; Eleştirel Inceleme - A.K.

Çıkar Çatışması: Yazarlar çıkar çatışması bildirmemişlerdir.

Finansal Destek: Yazarlar bu çalışma için finansal destek almadığını belirtmiştir.

\section{REFERENCES}

1. Karaman E, Yilmaz M, Ada M, Yilmaz RS, Isildak H. Unusual location of primary hydatid cyst: soft tissue mass in the parapharyngeal region. Dysphagia 2011; 26: 75-7. [CrossRef]

2. Iynen I, Sogut O, Guldur ME, Kose R, Kaya H, Bozkus F. Primary hydatid cyst: an unusual cause of a mass in the supraclavicular region of the neck. Journal of Clinical Medicine Research 2011; 3: 52-4.

3. Ok E, Sözüer EM. Solitary subcutaneous hydatid cyst: a case report. Am J Trop Med Hyg 2000; 62: 583-4.
4. Battyany I, Andrea L, Nagy KK. Subcutaneous hydatid cyst in the popliteal fossa at the site of a previous was psting. Diagn Interv Radiol 2011; 17: 163-5.

5. Beytur A, Karaman U, Samdanci ET, Yakupoğullari Y, Tatar Y. Olgu Sunumu: Primer Renal Hidatik Kist. Turkiye Parazitol Derg 2009; 33: 236-8.

6. Ramia-Angel JM, Gasz A, de la Plaza-Llamas R, Quinones-Sampedro J, Sancho E, Garcia Parreno J. Hidatidosis of the spleen. Pol Przegl Chir 2011; 83: 271-5. [CrossRef]

7. Turgut AT, Odev K, Kabaalioglu A, Bhatt S, Dogra VS. Multitechnique evaluation of renal hydatid disase. AJR Am J Roentgenol 2009; 192: 462-7. [CrossRef]

8. Şahin EM, Yüksek YN, Dağlar G. Diagnosis and Treatment of Hydatid Cysts: Results of 120 patients. Trakya Univ Tip Fak Derg 2008; 25: 6-14.

9. Von Lichtenberg F. Pathology of infectious diseases, Raven Press, New York. 1991 p. 331-335.

10. Mıman O, Atambay M, Aydin NE, Daldal N. The clinical, serological and morphological analysis of 91 patients with cystic echinococcosis following surgery. Turkiye Parazitol Derg 2010; 34: 179-83.

11. Terblanche J, Krige JEJ. Liver Echinococcosis. In: Cameron JL, editor. Current Surgical Therapy, sixth edition, Philadelphia. 2001. p 324-9

12. Blanton R. Ekinococcosis. In: Behrman RE, Jenson HB, Stanton BF. (Eds) Nelson Textbook of Pediatrics. Kliegman RM, Philadelphia: Saunders. 2007. p. 1516-9.

13. Schantz PM. Echinococcus Species (Agents of Cystic, Alveolar, and Polycystic Echinococcosis). In: Long SS, Pickering LK, Prober CG. (Eds). Principles and Practice of Pediatric Infectious Diseases Second Edition New York: Churchill-Livingstone. 2003. p. 1357-61.

14. Turgut AT, Altinok T, Topçu S, Koşar U. Local complications of hydatid disease involving thoracic cavity: Imaging findings. European Journal of Radiology 2009; 70: 49-56. [CrossRef]

15. Tuncer E, Tas SG, Mataraci I, Tuncer A, Donmez AA, Aksut M, et al. Surgical treatment of cardiac hydatid disease in 13 patients. Tex Heart Inst J 2010; 37: 189-93.

16. Işıkay S, Yılmaz K, Ölmez A. Two cases of rare cerebral hydatid cyst. Turkiye Parazitol Derg 2012; 36: 41-4. [CrossRef]

17. Bozbuga M, Celikoglu E, Boran BO. Hydatid cyst of the craniocervical junction: case report. Neurosurgery 2005; 57: 193-5. [CrossRef]

18. Razzaghi MR, Mazloomfard MM, Bahrami-Motlagh $\mathrm{H}$, Javanmard B. Isolated renal hydatid cyst: diagnosis and management. Urol J 2012; 9: 718-20.

19. Kuru C, Baysal B. Uniloküler kistik ekinokokkozisin tanısında indirect hemaglütinasyon yönteminin değeri. Türkiye Parazitol Derg 1999; 23: 251-4.

20. Delibas SB, Ozkoc S, Sahin S. Evaluation of Patients Presenting with a Suspicion of Cystic Echinococcosis to the Serology Laboratory of the Parasitology Department of Dokuz Eylül University Medical Faculty. Turkish Society for Parasitology 2006; 30: 279-81.

21. WHO Informal Working Group 1 International classification of ultrasound images in cystic echinococcosis for application in clinical and field epidemiological settings. Acta Tropica 2003; 85: 253-61. [CrossRef]

22. Gharbi HA, Hassine W, Brauner MW, Dupuch K. Ultrasound examination of the hydatid liver. Radiology 1981; 139: 459-63. [CrossRef]

23. Dervenis C, Delis S, Avgerinos C, Madariaga J, Milicevic M. Changing concepts in the management of liver hydatid disease. J Gastrointest Surg 2005; 9: 869-77. [CrossRef]

24. Brunetti E, Kern P, Vuitton DA, Writing Panel for the WHO-IWGE. Expert consensus for the diagnosis and treatment of cystic and alveolar echinococcosis in humans. Acta Trop 2010; 114: 1-16. [CrossRef] 
25. Kurul iC, Topcu S, Altinok T. One-stage operation for hydatid disease of lung and liver: Principles of treatment. J Thorac Cardiovasc Surg 2002; 124: 1212-5. [CrossRef]

26. Kartal A, Sahin M, Yol S, Belviranli M, Karahan O, Vatansev C, et al. The management of hepatic hydatid cyst cavity by overlapping. Ann Saudi Med 1998; 18: 82-3.

27. Sahin M, Kartal A, Haykir R, Cakir M. RF-assisted cystectomy and pericystectomy: a new technique in the treatment of liver hydatid disease. Eur Surg Res 2006; 38: 90-3. [CrossRef]
28. Aydin $Y$, Ogul H, Turkyilmaz A, Eroglu A Surgical treatment of mediastinal cysts: report on 29 cases. Acta Chir Belg 2012; 112: 281-6.

29. Junghanss T, da Silva AM, Horton J, Chiodini PL, Brunetti E. Clinical management of cystic echinococcosis: state of the art, problems, and perspectives. Am J Trop Med Hyg 2008; 79: 301-11.

30. Tekin A, Kartal A, Aksoy F, Vatansev C, Kücükkartallar T, Belviranli M, et al. Long-term results utilizing the unroofing technique in treating hydatid cysts of the liver. Surg Today 2008; 38: 801-6. [CrossRef] 